\title{
Akurasi Polymerase Ghain Reaction [PCR] Dibandingkan dengan Uji Tuberkulin untuk Diagnosis Tuberkulosis pada Anak
}

\author{
Nastiti Kaswandani, Darmawan B Setyanto, Nastiti Noenoeng Rahajoe \\ Departemen Ilmu Kesehatan Anak, RS Dr Cipto Mangunkusumo, Fakultas Kedokteran Universitas \\ Indonesia, Jakarta
}

Latar belakang. Penegakan diagnosis tuberkulosis (TB) pada anak sangat sulit, oleh karena gejalanya yang tidak khas serta sulitnya mendapatkan spesimen untuk pemeriksaan mikrobiologis. Uji tuberkulin telah lama digunakan sebagai salah satu pemeriksaan penunjang yang penting untuk diagnosis TB anak. Beberapa tahun terakhir telah dikembangkan pemeriksaan polymerase chain reaction (PCR) untuk mendeteksi TB. Tujuan. Menilai akurasi pemeriksaan PCR dalam penegakan diagnosis TB anak serta perbandingannya dengan uji tuberkulin.

Metode. Penelitian uji diagnosis yang menilai akurasi PCR terhadap baku emas diagnosis TB yaitu basil tahan asam (BTA) dan/atau biakan di RS Cipto Mangunkusumo, RSIA Harapan Kita, RS Budhi Asih, dan RS Persahabatan, tahun 2005-2007. Dilakukan pemeriksaan uji tuberkulin dan pengambilan spesimen dari dahak, bilasan lambung, cairan pleura, aspirasi kelenjar getah bening (dengan jarum halus), atau cairan serebrospinal untuk diperiksa PCR, sediaan langsung basil tahan asam dan biakan Mycobacterium tuberculosis.

Hasil. Dari 181 pasien anak tersangka TB (suspected TB), didapatkan 13 pasien yang didiagnosis pasti TB (confirmed TB) sehingga didapatkan prevalens $7,2 \%$. Sensitivitas dan spesifisitas PCR berturut-turut adalah $69 \%$ dan $57 \%$, sedangkan sensitivitas dan spesifisitas uji tuberkulin berturut-turut adalah $77 \%$ dan 55\%. Rasio kemungkinan positif (positive likelihood ratio) PCR dan uji tuberkulin berturut-turut adalah 1,62 dan 1,7 .

Kesimpulan. Penelitian ini mendapatkan bahwa PCR tidak lebih superior dibandingkan dengan uji tuberkulin untuk mendiagnosis TB pada anak. (Sari Pediatri 2010;12(1):42-6).

Kata kunci: polymerase chain reaction, uji tuberkulin, diagnosis, tuberkulosis anak

Alamat korespondensi:

Dr. Nastiti Kaswandani, Sp.A. Divisi Respirologi Departemen Ilmu Kesehatan Anak FKUI-RSCM Jl. Salemba no.6 Jakarta 10430. Telepon 021-3148930 Fax.021-3148931. E-mail: nkaswandani@yahoo.com
I ndonesia sampai saat ini menempati peringkat ketiga sebagai negara dengan pasien tuberkulosis (TB) terbanyak di dunia. ${ }^{1}$ Jumlah pasien TB akan meningkatkan risiko infeksi dan sakit TB pada anak Indonesia, meskipun risiko tersebut berbeda-beda di berbagai daerah di Indonesia. ${ }^{2,3}$ 
Penegakan diagnosis TB pada anak jauh lebih sulit dibandingkan pada dewasa. Gejala-gejala TB pada anak tidak khas, mirip dengan gejala penyakit infeksi atau penyakit kronik lainnya. Pemeriksaan penunjang untuk membantu penegakan diagnosispun memiliki permasalahan yang cukup kompleks. Jika pada dewasa pemeriksaan sputum dapat memberikan informasi yang akurat namun pada anak sulit dilakukan. Meskipun bisa diganti dengan pemeriksaan bilasan lambung, namun persentase hasil yang positif sangat kecil. $^{4-7}$

Salah satu pemeriksaan penunjang yang digunakan untuk mendeteksi terjadinya infeksi TB pada anak adalah pemeriksaan uji tuberkulin. Uji tuberkulin mempunyai sensitivitas dan spesifisitas yang cukup tinggi untuk menentukan ada tidaknya infeksi TB, khususnya pada anak. Namun demikian uji tuberkulin memiliki kekurangan, di antaranya adalah tidak dapat membedakan antara infeksi laten TB dan penyakit TB aktif serta adanya hasil negatif palsu karena anergi serta positif palsu karena reaksi silang dengan bacillus calmette guerin (BCG) dan infeksi mycobacterium lainnya. ${ }^{4-7}$

Pemeriksaan yang pada akhir-akhir ini banyak dikerjakan di negara maju maupun negara berkembang lainnya adalah pemeriksan PCR TB. Pemeriksaan PCR merupakan pemeriksaan mikrobiologi yang didasarkan pada amplifikasi regio asam nukleat tertentu yang spesifik pada Mycobacterium tuberculosis. ${ }^{8}$ Penelitian pada spesimen pasien TB dewasa sudah banyak dilakukan. Namun demikian penelitian yang menghasilkan bukti tentang akurasi pemeriksaan ini pada anak masih belum sebanyak penelitian pada orang dewasa. Penelitian kami bertujuan untuk mengevaluasi akurasi PCR dalam menentukan adanya penyakit TB pada anak dan membandingkan akurasi PCR dengan uji tuberkulin dalam menentukan adanya penyakit TB pada anak.

\section{Metode}

Penelitian merupakan suatu uji diagnosis yang mengevaluasi akurasi PCR untuk mendiagnosis penyakit TB pada anak, dibandingkan dengan pemeriksaan uji tuberkulin yang telah lama digunakan sebagai pemeriksaan penunjang. Merupakan bagian dari penelitian multisenter mengenai skoring TB Anak pada tahun 2005-2007. Subyek penelitian adalah pasien dari empat rumah sakit di Jakarta, yaitu RS Cipto Mangunkusumo, RSIA Harapan Kita, RS Budhi Asih, dan RS Persahabatan.

Kriteria inklusi adalah pasien berusia 0-14 tahun yang datang dengan kecurigaan penyakit TB (suspected TB), yaitu apabila terdapat salah satu dari gejala batuk yang menetap minimal tiga minggu dengan kemungkinan penyebab lain telah disingkirkan, berat badan menurut umur kurang dari $80 \%$ berat badan ideal, gejala sakit yang tidak jelas penyebabnya yang sudah berlangsung selama minimal dua minggu (termasuk di dalamnya gejala demam berkepanjangan, keluhan gastrointestinal yang tidak jelas penyebabnya). Kriteria eksklusi adalah pasien yang orangtuanya menolak berpartisipasi dalam penelitian.

Seluruh pasien yang memenuhi kriteria inklusi menjalani pengambilan spesimen dari dahak / bilasan lambung / cairan pleura / aspirasi kelenjar getah bening (dengan jarum halus) atau cairan serebrospinal. Uji tuberkulin dikerjakan pada seluruh subyek. Terhadap seluruh spesimen dilakukan pemeriksaan PCR, sediaan langsung basil tahan asam, dan biakan Mycobacterium tuberculosis. Baku emas uji diagnosis ini adalah hasil yang positif pada pemeriksaan sediaan langsung basil tahan asam dan/atau biakan Mycobacterium tuberculosis positif.

Pemeriksaan uji tuberkulin dilakukan dan dibaca oleh dokter yang menangani pasien tanpa mengetahui hasil pemeriksaan PCR dan BTA serta biakan dan sebaliknya ahli mikrobiologi yang melakukan pemeriksaan tidak mengetahui data klinis pasien. Uji tuberkulin dikerjakan dengan menggunakan PPD RT23 2TU yang diproduksi oleh Staten Serum Institute, Kopenhagen, Denmark. Petugas yang melakukan uji tuberkulin adalah perawat yang sudah dilatih secara khusus. Setelah $48-72$ jam penyuntikan, dokter peneliti membaca hasil uji tuberkulin dengan metode "ballpoint". Uji tuberkulin dinyatakan positif apabila didapatkan diameter indurasi $10 \mathrm{~mm}$ atau lebih (tanpa melihat status BCG).

Protokol pemeriksaan PCR menggunakan deteksi molekular IS6110. IS 6110 tidak dapat membedakan strain maupun MOTT (mycobacterium other than tuberculosis). Prosedur PCR meliputi isolasi DNA dan amplifikasi IS6110 untuk diagnosis Mycobacterium tuberculosis. Pewarnaan sediaan langsung untuk mendeteksi BTA menggunakan dua cara yaitu Auramin dan Ziehl Neelsen. Hasil positif pada Auramin akan 
dikonfirmasi dengan Ziehl Neelsen untuk konfirmasi diagnosis TB.

Seluruh spesimen dibiak pada media solid Lowenstein-Jensen dan dikonfirmasi sebagai Mycobacterium tuberculosis melalui uji konfirmasi serial seperti uji Niasin, reduksi nitrat dan uji katalase. Seluruh orangtua pasien telah menyatakan persetujuannya untuk mengikuti penelitian ini secara tertulis dan telah mendapat ijin dari komite etik. Data yang diperoleh diolah dan disajikan dengan menggunakan program SPSS 17.

\section{Hasil}

Didapatkan 181 pasien dengan diagnosis tersangka tuberkulosis yang dievaluasi dengan anamnesis, pemeriksaan fisis dan pemeriksaan penunjang berupa uji tuberkulin, PCR, BTA dan kultur. Sebagian besar spesimen berupa bilasan lambung. Dari 181 pasien yang diperiksa, terdapat 13 pasien yang sediaan BTA langsung dan/atau biakan positif Mycobacterium tuberculosis. Terdapat empat spesimen dengan hasil sediaan BTA langsung positif tetapi pada biakan tidak tumbuh. Karakteristik subyek penelitian tertera pada Tabel 1.

Prevalens diagnosis TB pasti pada studi ini adalah $7,2 \%$. Spesimen yang diperiksa sebagian besar adalah bilasan lambung. Bilasan lambung diperiksa dua hari berturut-turut. Hasil pemeriksaan uji tuberkulin pada subyek dibandingkan dengan hasil pulasan BTA dan/ atau biakan Mycobacterium tuberculosis tertera pada Tabel 2.

Hasil pemeriksaan PCR pada subyek dibandingkan dengan hasil pulasan BTA dan/atau biakan Mycobacterium tuberculosis tertera pada Tabel 3.

Selain dilakukan perhitungan sensitivitas dan spesifisitas terhadap PCR dan uji tuberkulin, dilakukan pula penilaian terhadap nilai-nilai diagnostik lainnya seperti tertera pada Tabel 4.

Tabel 1. Karakteristik subyek

\begin{tabular}{lc}
\hline Karakteristik & $\mathrm{n}$ (persentase) \\
\hline Jenis kelamin & \\
$\quad$ Laki-laki & $80(44.2)$ \\
$\quad$ Perempuan & $101(55.8)$ \\
Rerata usia (bulan) & 49.7 \\
Diagnosis kerja & \\
$\quad$ TB paru & $154(85.1)$ \\
$\quad$ Limfadenitis TB & $19(10.5)$ \\
TB milier & $3(1.6)$ \\
Spondilitis TB & $3(1.6)$ \\
$\quad$ Meningitis TB & $2(1.2)$ \\
Confirmed TB & $13(7.2)$ \\
Pulasan BTA positif & $10(5.5)$ \\
Biakan M. tuberkulosis positif & $7(3.9)$ \\
Biakan MOTT positif & $5(2.8)$ \\
\hline
\end{tabular}

Tabel 2. Hasil pemeriksaan uji tuberkulin dibandingkan dengan BTA/kultur

\begin{tabular}{lcc}
\hline Uji tuberkulin & BTA/kultur positif & BTA/kultur negatif \\
\hline Positif & 10 & 76 \\
Negatif & 3 & 92 \\
\hline
\end{tabular}

Tabel 3. Hasil pemeriksaan PCR dibandingkan dengan BTA/kultur

\begin{tabular}{lcc}
\hline PCR & BTA/kultur positif & BTA/kultur negatif \\
\hline Positif & 9 & 72 \\
Negatif & 4 & 96 \\
\hline
\end{tabular}

Tabel 4. Perbandingan nilai diagnostik uji tuberkulin dan PCR

\begin{tabular}{lcc}
\hline Nilai diagnostik & Uji tuberkulin & PCR \\
\hline Sensitivitas & $77 \%(95 \%$ IK 54 -100) & $69 \%(95 \%$ IK 44-94) \\
Spesifisitas & $55 \%(95 \%$ IK 47 - 62) & $57 \%(95 \%$ IK 50- 65) \\
Nilai prediksi positif & $12 \%(95 \%$ IK 5- 18) & $11 \%(95 \%$ IK 4 -18 ) \\
Nilai prediksi negatif & $97 \%(95 \%$ IK 93-100) & $96 \%(95 \%$ IK 92-100) \\
Rasio kemungkinan positif & $1,70(95 \%$ IK 1.21- 2.39$)$ & $1,62(95 \%$ IK 1.08-2.42) \\
Rasio kemungkinan negatif & $0,42(95 \%$ IK 0.15-1.15) & $0,54(95 \%$ IK 0.24-1.23) \\
\hline
\end{tabular}




\section{Diskusi}

Kelemahan penelitian kami adalah jumlah subyek yang terlalu sedikit dan prevalens yang rendah akibat terlalu longgarnya kriteria inklusi dalam menentukan kecurigaan terhadap TB. Kami mendapatkan prevalens subyek confirmed TB 7,2\% lebih rendah dibandingkan dengan studi yang lain. Penelitian oleh Chaudhary ${ }^{9}$ di India mendapatkan TB confirmed 19,35\% (6 dari 31 pasien TB), sedangkan Khalilzadeh ${ }^{10}$ di Iran mendapatkan angka confirmed TB sebesar 58,7\%.

Batuk selama tiga minggu merupakan salah satu kriteria inklusi yang longgar. Batuk kronik pada bayi dapat terjadi karena post viral cough, pertussis atau hiperreaktivitas. Pada anak yang lebih besar, batuk kronik dapat merupakan gejala sinusitis atau asma. Marais ${ }^{4}$ menemukan bahwa gejala batuk pada TB memiliki karakteristik batuk non-remitting atau batuk persisten yang terus-menerus. Dalam studi kami memasukkan semua pasien tersangka TB sebelum dilakukan foto radiologi.

Gray $^{11}$ mendapatkan persentase biakan positif lebih tinggi pada pasien yang memiliki kelainan radiologis berat dibandingkan dengan gambaran radiologis hanya berupa pembesaran kelenjar getah bening hilus. Biakan dengan menggunakan media cair seperti MGIT dan BACTEC juga memberikan sensitivitas yang lebih tinggi serta waktu yang lebih singkat dibandingkan dengan media Lowenstein-Jensen yang digunakan pada penelitian kami.

Sensitivitas PCR pada studi kami lebih rendah dari studi yang pernah dilaporkan sebelumnya. Parvez $\mathrm{dkk}^{12}$ di Bangladesh mengevaluasi akurasi PCR terhadap biakan $M$ tuberculosis sebagai baku emas dan mendapatkan hasil bahwa sensitivitas PCR adalah $92 \%$ dan spesifisitas $70 \%$. Penelitian di India oleh Negi $\mathrm{dkk}^{13}$ mendapatkan sensitivitas dan spesifisitas PCR pada pasien TB dewasa 74,4\% dan $97,3 \%$. Suatu metaanalisis yang mengevaluasi studi tentang PCR untuk diagnosis TB pada pasien TB dewasa dengan BTA negatif mendapatkan bahwa sensitivitas PCR memiliki rentang lebar yaitu antara 9 sampai $100 \%$ dan spesifisitas berkisar antara 25-100\%. ${ }^{14}$ Studi mengenai akurasi PCR pada anak jauh lebih sedikit dibandingkan pada dewasa. Sebuah studi di Teheran, Iran menunjukkan bahwa dari 126 anak yang telah didiagnosis TB, dilaporkan mempunyai persentase PCR, BTA dan biakan positif berturut-turut $53,2 \%, 55,6 \%$ dan $58,7 \% .^{10}$ Penelitian lain di India sebelumnya mendapatkan bahwa dari 31 pasien anak dengan TB aktif, 12 di antaranya menunjukkan hasil PCR positif, dan jika merujuk biakan sebagai baku emas maka sensitivitas PCR 100\%.

Dari beberapa spesimen dengan PCR positif, ternyata pada biakan kuman yang tumbuh adalah MOTT (mycobacterium other than tuberculosis), hal ini disebabkan karena molekul IS6110 yang digunakan tidak mampu membedakannya. Didapatkan spesimen dengan BTA positif tetapi pada biakan tidak didapatkan pertumbuhan Mycobacterium tuberculosis atau MOTT. Kemungkinan besar disebabkan oleh ketidaksempurnaan dalam rangkaian proses perlakuan terhadap spesimen, antara lain teknik pengiriman spesimen, waktu tunggu spesimen sampai dilakukan pemeriksaan serta teknik pembiakan. ${ }^{8}$

Spesimen terbanyak yang diperiksa berasal dari bilasan lambung. Sulitnya pengambilan spesimen sputum atau bilasan lambung pada anak menyebabkan perlu ditelusuri alternatif spesimen lain untuk pemeriksaan PCR TB. Khan ${ }^{15}$ melakukan penelitian akurasi PCR darah tepi pada pasien TB paru dewasa dan mendapatkan sensitivitas yang rendah yaitu $14.5 \%$ sehingga tidak membantu meningkatkan sensitivitas PCR. Masalah yang harus dicermati dalam pemeriksaan PCR adalah tinggi nilai risiko positif palsu akibat kontaminasi spesimen atau turut terdeteksinya kuman yang telah mati. Suatu studi di Peru mencoba melakukan uji diagnosis PCR dengan menggunakan feses sebagai spesimen namun mendapatkan sensitivitas yang sangat rendah, didapatkan $38 \%{ }^{16}$

\section{Kesimpulan}

Untuk mendiagnosis TB pada anak, PCR tidak menunjukkan keunggulan dalam nilai-nilai diagnostik (sensitivitas, spesifisitas, dan lainnya) dibandingkan dengan uji tuberkulin. Diperlukan penelitian uji diagnosis dengan skala yang lebih besar dengan inklusi yang lebih ketat untuk memperoleh kekuatan penelitian yang lebih tinggi. Penulis merekomendasikan untuk melakukan anamnesis yang cermat, pemeriksaan fisis yang seksama, dan melakukan pemeriksaan penunjang yang penting seperti uji tuberkulin dan foto radiologik untuk menegakkan diagnosis TB pada anak. 


\section{Daftar Pustaka}

1. World Health Organization. WHO report 2008: Global tuberculosis control: surveillance, planning and financing. Geneva: WHO; 2008.

2. Bactiar A, Miko TY, Machmud R. Annual risk of tuberculosis infection in West Sumatra Province, Indonesia. Int J Tuberc Lung Dis 2008;12:255-61.

3. Bactiar A, Miko TY, Machmud R. Annual risk of tuberculosis infection in East Nusa Tenggara and Central Java Provinces, Indonesia. Int J Tuberc Lung Dis 2009; 13:32-8.

4. Marais BJ, Gie RP, Schaaf HS, Beyers N, Donald PR, Starke JR. Childhood pulmonary tuberculosis: old wisdom and new challenge. Am J Respir Crit Care Med 2006; 173:1078-90.

5. Marais BJ, Pai M. Recent advances in the diagnosis of childhood tuberculosis. Arch Dis Child 2007;92:44652.

6. Shingadia D, Burgner D. Mycobacterium infection. Dalam: Taussig LM, Landau LI, penyunting. Pediatric Respiratory Medicine. Edisi kedua. Philadelphia: Mosby Elsevier; 2008. h.597-614.

7. Marais BJ, Schaaf HS, Donald PR. Management algorithms for paediatric tuberculosis. Dalam: Schaaf HS, Zumla AI, penyunting. Tuberculosis: a comprehensive clinical reference. St Louis: Elsevier; 2009.h.323-31.

8. Rattan A. PCR for diagnosis of tuberculosis: where are we now?. Ind J Tub 2000;47:79-81.
9. Chaudary M, Baveja CP, Sharma VK, Sethi GR. Clinical utility of Polymerase Chain Reaction for improved diagnosis of pulmonary tuberculosis in children. Indian J Tuberculosis 2006;53:212-6.

10. Khalilzadeh S, Baghaie N, Zamani A, Aghaei JS, Boloorsaz MR, Velayati AA. Bacteriological evaluation for diagnosis of tuberculosis in children. Tannafos 2009;8:42-5.

11. Gray JW. Childhood tuberculosis and its early diagnosis. Clin Biochem 2004;37:450-5.

12. Parvez MAK, Hasan KN, Rumi MAK. PCR can help early diagnosis of pulmonary tuberculosis. Southeast Asian J Trop Med Public Health 2003;34:147-53.

13. Negi SS, Khan SFB, Gupta S, Pasha ST, Khare S, Lal S. Comparison of the conventional diagnostic modalities, Bactec culture and polymerase chain reaction test for diagnosis of tuberculosis. Indian J Med Microbiol 2005;23:29-33.

14. Sarmiento OL, Weigle KA, Alexander J, Weber DJ, Miller WC. Assessment by meta-analysis of PCR for diagnosis of smear negative pulmonary tuberculosis. J Clin Microbiol 2003;41:3233-40.

15. Khan MA, Mirza SH, Abbasi SA, Butt T, Anwar M. Peripheral blood-based polymerase chain reaction in diagnosis of pulmonary tuberculosis. J Ayub Med Coll Abbottabad 2006;18:25-8.

16. Wolf H, Mendez M, Gilman RH. Diagnosis of pediatric pulmonary tuberculosis by stool PCR. Am J Trop Med Hyg 2008;79:893-8. 